PHOTOGRAPHS OF THE AURORA.

$A N$ important advance in the knowledge of the $A$ aurora is the outcome of the spring expedition to Bossekop, under M. Carl Störmer. This

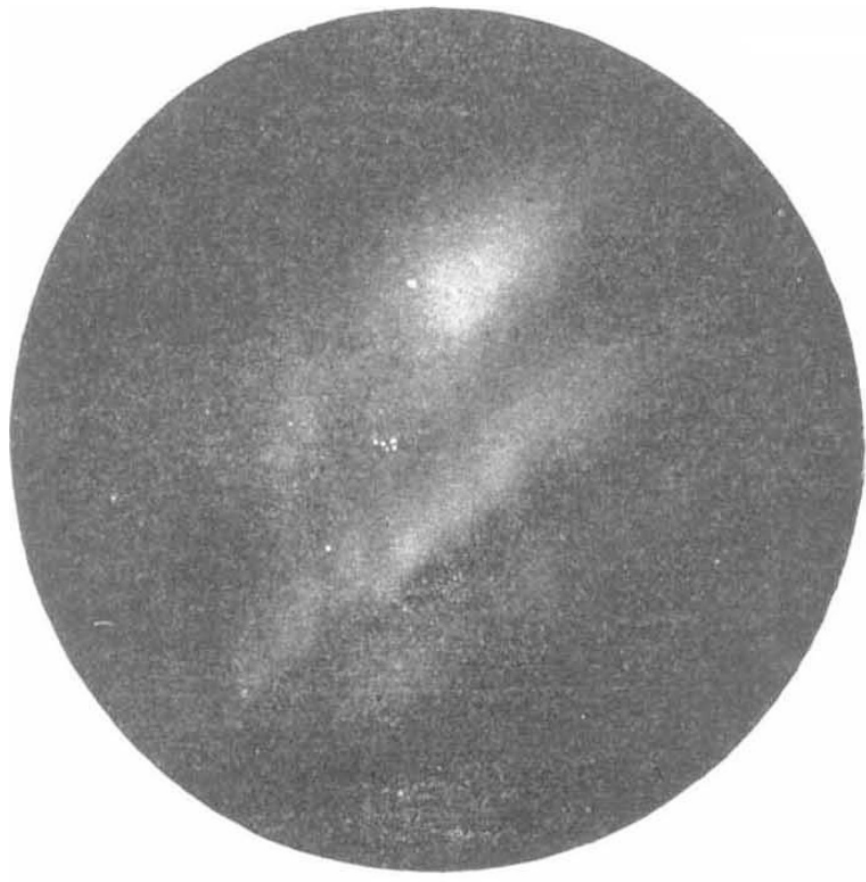

Dimatkoj.

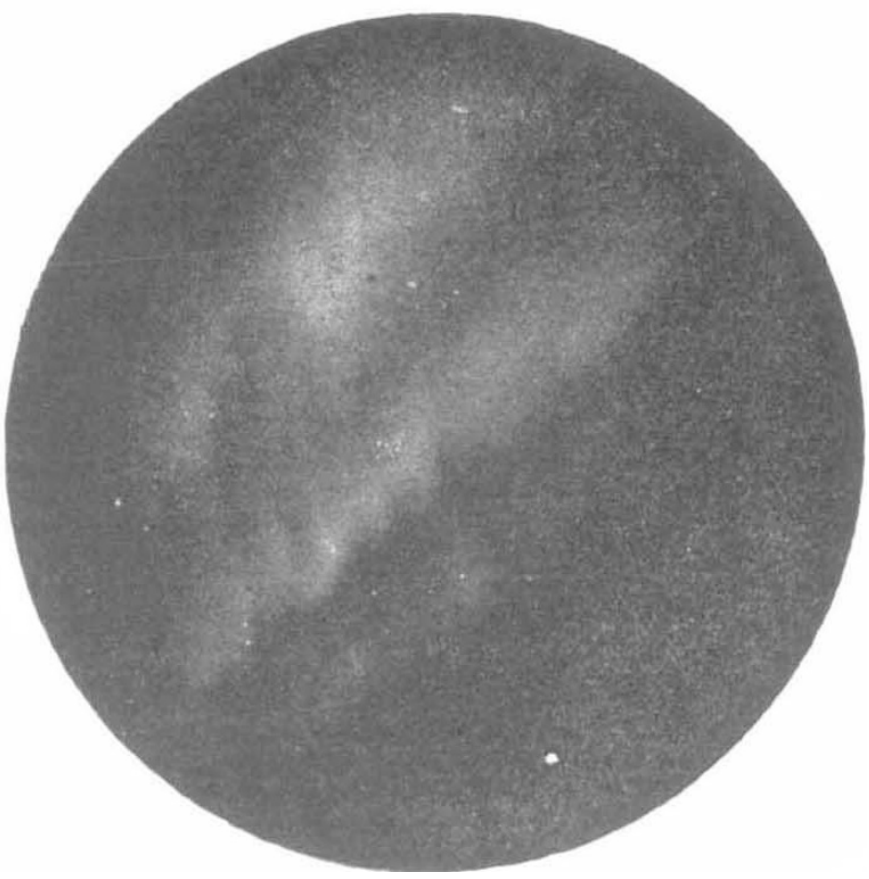

Korsnes. Fig. I. - Photograph of the same aurora taken on March 3 , ror 3 , at roh. $36 \mathrm{~m}$., Central 30
European time, from Bossekop and Korsnes.
M. Carl Störmer has re-
M. cently but very briefly communicated an account of the research to the Paris Acad e m y (Comptes rendus, June 16 ).

From February 28 to April I of the present year the expedition secured 636 pairs of simultaneous photographs of the aurora at the two stations, namely, Bossekop and St or e Korsnes, the latter station being about 27 kilometres to the north of Bossekop. Of these photographs $45^{\circ}$ pairs are stated to be very satisfactory and furnish material sufficient to compute with a large degree of accuracy the for $\mathrm{m}$, position, and altitude of all the principal kinds of aurora borealis.

Further, exactly at the same time as the photographs of the aurora were taken, other photographs, with a prismatic camera, were secured. On these latter photographs can be seen not only the spectra of the stars, but several su perposed impressions of $\mathrm{the}$ auroræ corresponding to different spectrum lines.

As in I9Io, a kinematograph was employed to try to secure the changing phases

expedition was undertaken to complete the work done in the rgro expedition, which. was so fruitful of results. The experience gained on the first of the aurora: for the most part the auroral images were too faint. On three occasions, how-

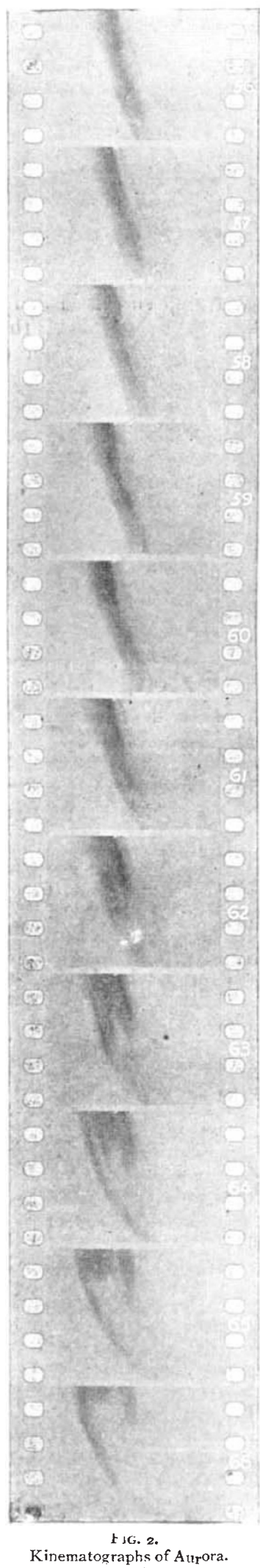

NO. 2284 , VOL. 9I] 
ever, when the auroræ were very bright, consecutive exposures were given, lasting from $0^{\circ} 5$ second to I second for each image.

Another series of about roo photographs was taken on April 8 with the kinematograph, each exposure lasting about four seconds. These photographs demonstrate the great utility of this instrument not only in obtaining consecutive features of the displays, but in securing ordinary photographs at the two stations. The communication is accompanied by two most interesting plates. The first of these shows excellent reproductions of the aurora on March 3, photographed at the two stations at the same time, with clear impressions of the stars, demonstrating at a glance the parallactic effect (Fig I). The second plate reproduces four portions of the kinematograph strip exposed on April 8 at Bossekop. These speak for themselves in indicating the valuable aid the kinematograph brings to auroral studies. A portion of these strips is here reproduced, the exposures for each portion being four seconds (Fig. 2). The gradual change in form and density of the filaments illustrated is here clearly indicated. $M$. Störmer states that the results of this expedition will be published in considerable detail in a subsequent memoir, and the above brief summary is sufficient to show that the memoir will be a most valuable contribution to our knowledge of the aurora.

\section{THE INTERNATIONAL MEDICAL CONGRESS.}

$\mathrm{T}^{\mathrm{H}}$ E International Medical Congress, which is now meeting in London, may fairly be described as the greatest scientific congress ever held in the metropolis; for the time has gone for ever when a medical congress can be confined to the sciences commonly thought of as medical, and it is probable that the future will remember with most gratitude those contributions to the present congress which may seem to have the least relation to medicine.

No single fact marks better the advance of medical thought since last the congress met in London, thirty-two years ago, than the delivery of an address by Mr. W. Bateson on heredity. The supreme names of the past may have no living parallels, but their work bears fruit. Pasteur is gone, but the bacteriologists are all in force at the congress, and his pupil Laveran, who discovered the parasite of malaria a generation ago, is here to see, at any rate in tropical medicine, something like the realisation of his master's dictum that "it is in the power of man to make all parasitic diseases disappear from the earth." Lister is not here, but Prof. Cushing can scarcely fail to refer to the surgery of the pituitary body, which seemed wildly impossible only a few years ago. Jonathan Hutchinson is not here, but Prof. Ehrlich will report on the modern treatment of syphilis, though Schaudinn, who found the spirochæte, did not live to hear of salvarsan. NO. 2284 , VOL. 9I]
The congress will greatly serve science, but it may still more greatly serve public opinion, and even develop something like public wisdom in some respects. The international resolution on the value of vivisection will be an illustration of this, and also the discussion on alcohol and degeneracy; but most may be hoped from the discussion, in the Albert Hall itself, of the duty of the State in respect of syphilis. This can scarcely fail to reinforce the demand for a Royal Commission lately made by the leaders of medicine in this country, supported by the British Medical Association at Brighton, and repeated by the English-Speaking Conference on Infant Mortality in London on Tuesday, on behalf of absolute innocence, now commonly murdered by our immoral neglect of this subject.

\section{THE RIVERS OF THE SCOTTISH LOWLANDS. ${ }^{1}$}

$T^{\mathrm{H}}$ $\mathrm{HE}$ handsome volume before us is about evenly divided between the physiographic and industrial questions of the Forth area, and in this combination of interests serves to remind us of the enormous scope of modern geography.

$\mathrm{Mr}$. Cadell has qualified himself to be the historian of the Forth by a long period of service in the Geological Survey of Scotland; and for the subjects treated in the latter half of the book by an almost equally long period of public service in the Lothians.

The history of the Forth begins naturally with the origin of the solid rocks which form the floor of its valley. These foundation-stones were laid in the far-off times of the Old Red Sandstone lakes and the steamy swamps of the Carboniferous. In the first three chapters an excellent light treatment of the many points of interest in connection with the deposition of these rocks, especially the economic materials they contain, is given. After the formation of this basement there must have been a long period of peneplanation, then submergence, and finally re-emergence of the peneplane with a slight tilt en bloc to the east. This tilt determined the -direction of the Forth and other consequent rivers.

The most original and interesting portion of the book; perhaps, is that which deals with the development of the river system. The Forth, however, cannot be treated in this respect as a separate entity. Its origin involves that of the Clyde and Tweed, and also the lochs of Dumbartonshire and Argyllshire. The Forth originally rose in the highlands of the latter counties, but its headwaters were captured by an energetic stream which flowed southward down what is now the Firth of Clyde. The well-marked narrow trench crossing the Midland Valley from Clydebank to Grangemouth is now occupied by small streams totally disproportionate to its size, and is regarded by Mr. Cadell as the course of a former large tributary of the Forth. The Clyde 1 "The Story of the Forth." By H. M. Cadell. Pp. xvii+299tplates Glasgow: James Maclehose and Sons, I913.) Price I6s. net. 